\title{
Melanocortin Receptor 4
}

National Cancer Institute

\section{Source}

National Cancer Institute. Melanocortin Receptor 4. NCI Thesaurus. Code C131300.

Melanocortin receptor 4 (332 aa, $\sim 37 \mathrm{kDa}$ ) is encoded by the human MC4R gene. This protein plays a role in $\mathrm{G}$ protein-coupled receptor signaling. 